\title{
3,5-キシレノールーホルムアルデヒド樹脂カーボンの $\boldsymbol{c}$ 軸方向への炭素原子の変位とその温度依存性
}

\author{
(1973 年 8 月 15 日 受 理) \\ 白 石 稔*. 小林 和 夫**
}

\begin{abstract}
3, 5-キシレノールーホルムアルデヒド樹脂カーボンについて, 炭素原子の $c$ 軸方向の変位とその温度 依存性を調べた。その結果, 炭素原子の $c$ 軸方向の静的变位の二乗平均 $\overline{u_{\mathrm{s}}^{2}}$ は $c$ 軸長 $c_{0}$ の $6.86 \AA$ から $6.85 \AA$ までの減少にともなって，急激に減少する。 $c_{0}$ が $6.80 \AA$ 付近では屈曲を示し，さらに $c_{0}$ が 減少するとふたたび減少し， $c_{0}=6.76 \AA$ で $0.011 \AA^{2}$ を示した。一方，炭素原子の $c$ 軸方向の熱振動に よる二乗平均変位 $\overline{u_{\mathrm{v}}^{2}}$ は, $20^{\circ} \mathrm{C}$ 飞おいて $c_{0}$ の減少にともない $0.015 \AA^{2}$ からわずかに減少して $0.012 \AA^{2}$ を示した。また， $\overline{u_{\mathrm{v}}^{2}}$ は測定温度の上昇にともなってほぼ直線的に大きく増加して，約 $1000^{\circ} \mathrm{C}$ 拗いて 室温の約 4 倍になった。

高温側に和ける層面間の熱膨張は炭素原子の静的な変位よりも，炭素原子の熱振動に大きく影響され ることが知られた。このことから，どの試料についてもほぼ同一の層面間の熱膨張を示すことが理解さ れた。
\end{abstract}

\section{1 緒 言}

易黑鉛化性炭素を黑鉛化した場合， $c$ 軸長は大きく減少する。 しかし，㬝面自身は黒鉛状の炭素原子の六角網面をはじめからも っており，黒鉛化によりその層面は大きくなるが，その内部構造 は変わらないと見なされている1)。一方，Maire と Mering らは 層面自身の内部構造を問題にし, 黒鉛化にともない層面の内部構 造も変化する黒鉛化のモデルを提案している2)。著者らは層面に 属する炭素原子の $c$ 軸方向の变位を問題にして, その観点から易 黒鉛化性炭素の黒鉛化機構を明らかにしょらとしている3)。

一般に易黒鉛化性炭素といわれている炭素の中でも針状性のも のとそらでないもの，また熱膨張の大きいるのと小さいるのとい った性質の異なる炭素が知られている。そこで，易黒鉛化性炭素 の黒鉛化現象を観察する場合にる数種の炭素について測定すべき である。著者らは石油コークス,ピッチコークス，ポリ塩化ビニ ール炭化物，3，5-キシレノールーホルムアルデヒド樹脂炭化物に ついて, 層面間距離の熱膨張, 層面を構成している炭素原子の $c$ 軸方向への変位の大きさの測定を継続中である。本報に拄いては 易黒鉛化性炭素であるが， $400^{\circ} \mathrm{C}$ 前後に加熱後偏光影徽鏡下で観 測するとモザイク状の組織を示す 3,5 -キシンノールーホルムフ ルデヒド樹脂（以下 XF と略記する）炭化物刨を $1800^{\circ} \mathrm{C}$ から

* 工業技術院 公害資源研究所, 332 川口市寿町

**工業技術院 九州工業技術試験所, 841 鳥栖市宿町

1) たとえば, R.E. Franklin, Acta Cryst., 4, 253(1951).

2) J. Maire, J. Mering, "Chemistry and Physics of Carbon", Marcel Dekker Inc., New York (1970) Vol. 6, p. 125.

3) M. Shiraishi, K. Kobayashi, S. Toyoda, Carbon, 10 , 553(1972).

4) Y.Sanada, T. Furuta, H. Kimura, H. Honda, Fuel, 52, 143(1973). $3000^{\circ} \mathrm{C}$ まで熱処理して得た XF カーボンについて，炭素原子の 静的二乗平均変位, 熱振動による二乗平均変位およびそれの温度 依存性を測定し，試料の熱処理温度との関係を調べた。また，石 油コークスの場合と比較検討した。

\section{2 実験}

\section{1 実験試料}

$\mathrm{NaOH}$ 触媒下で XF を合成し，900豆 まで炭化した XF 炭を アルゴンガス雾囲気中で $1800 \sim 3000^{\circ} \mathrm{C}$ の各温度で 15 分間保持 して得たカーボンを使用した。

\section{2 二乗平均变位 $\overline{\boldsymbol{u}_{\mathrm{v}}^{2}}$ の測定}

既報3) と同様に, $\mathrm{Cu} K_{\alpha}$ 線をX 線源としたディフラクトメータ 一を使ってカーボンの 002，004，006 反射強度を, 波高分析器と シンチレーションカウンターによって湘定した。002 反射強度の 測定のさいには $\mathrm{Ni}$ ハクを挿入してX線を弱めて, シンチレーシ ョンカウンターの直線性の範团に入るよらにした。

回折線の面積を測って測定強度とした。吸収の補正は測定試料 ごとに試料の見かけの線吸収係数をX線の透過によって測定し， その值を使って試料ごとの四収因子を算出して補正した。

006 回折線は 112 回折線との重なりが見られた。その場 合に は, 112 回折線の低角側のプロフィルをその頂点からの垂線に対 称飞高角側に折りかえして, 雨回折線を分離して 006 反射強度を 求めた。

また，008回折線を測定したが，強度が弱いために誤差が大き くデータとして採用できなかった。

$002,004,006$ 強度の相対值から層面の平均位置から $c$ 軸方向 への二乗平均変位 $\overline{u_{\mathrm{c}}^{2}}$ を算出した ${ }^{3)}$ 。

2.3 炭素原子の熱振動による二乗平均变位 $\overline{\boldsymbol{u}_{\mathrm{v}}^{2}}$ の測定 試料の 004 強度を室温から $900^{\circ} \mathrm{C}$ まて測定し, その強度の温 
度変化から炭素原子の熱振動による二乗平均変位の大きさ $\overline{u_{\mathrm{V}}^{2}}$ 求めた ${ }^{9)(5)}$

\section{3 実 験 結 果}

\section{$3.1 \overline{\boldsymbol{u}_{\mathrm{c}}^{2}}$ の熱処理温度 HTT にともなう変化}

カーボンの钼測した $00 l$ 強度をLorentz ・偏光因子, 吸収因 子, 原子散乱因子の二乗で補正した強度の対数を稆軸に, $\sin ^{2} \theta /$ $\lambda^{2}$ ( $\theta$ は Bragg 角, 入はX線の波長) を横軸にプロットすると 因 1 のよらになる。因 1 には，1810，2210 牡よび $3040^{\circ} \mathrm{C}$ の各温 度で熱処理された試料について示した。004 強度がいくぶん強 く, 002，004，006 反射強度が完全に值線上にのらないが，直線 の勾配扣よび直線からのバラッキから $\overline{u_{\mathrm{c}}^{2}}$ 牤よびその誤差を算出 した。他の試料の $00 l$ 強度のバラッキも図 1 に示した程度であっ た。その各強度は図 1 中の $\mathrm{HTT} 3040^{\circ} \mathrm{C}$ と $\mathrm{HTT} 1810^{\circ} \mathrm{C}$ の $00 \mathrm{l}$ 強度の間に入った。

図 2 に HTT と炭素原子の $c$ 軸方向への二乗平均変位 $\overline{u_{\mathrm{c}}^{2}}$ の関 係を示した。四 2 の各測定点に括ける綎線は確率誤差の大きさを 示している。 $\overline{u_{\mathrm{c}}^{2}}$ は $\mathrm{HTT} 1810^{\circ} \mathrm{C} て ゙ 0.053 \pm 0.006 \AA^{2}$ を示し, HTT が増すにつれて減少し, $2210^{\circ} \mathrm{C} て ゙ ~ 0.030 \pm 0.005 \AA^{2}$ にな る。さらに, HTT が增すと $\overline{u_{\mathrm{c}}^{2}}$ は増加して $2430^{\circ} \mathrm{C} て ゙ ~ 0.036 \pm$ $0.006 \AA^{2}$ を示し, さらに HTT が增すと $\overline{u_{\mathrm{c}}^{2}}$ はふたたび減少し て, $3040^{\circ} \mathrm{C}$ では $0.023 \pm 0.003 \AA^{2}$ となった。

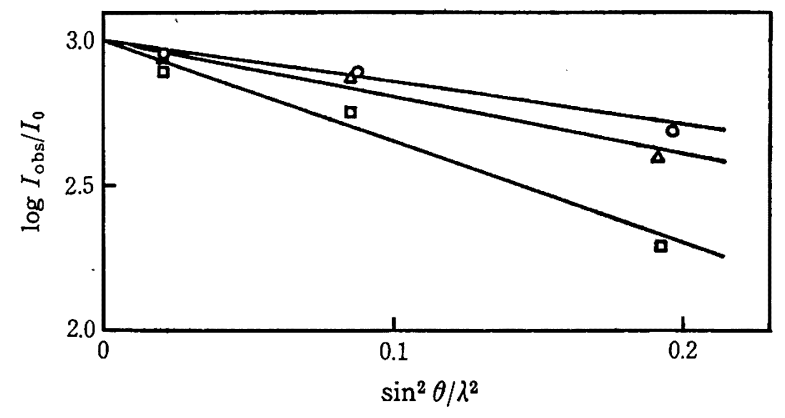

Fig. 1 Plot of $\log I_{\mathrm{obs}} / I_{0}$ vs. $\sin ^{2} \theta / \lambda^{2}$ at room temperature

HTT $\left({ }^{\circ} \mathrm{C}\right)-$

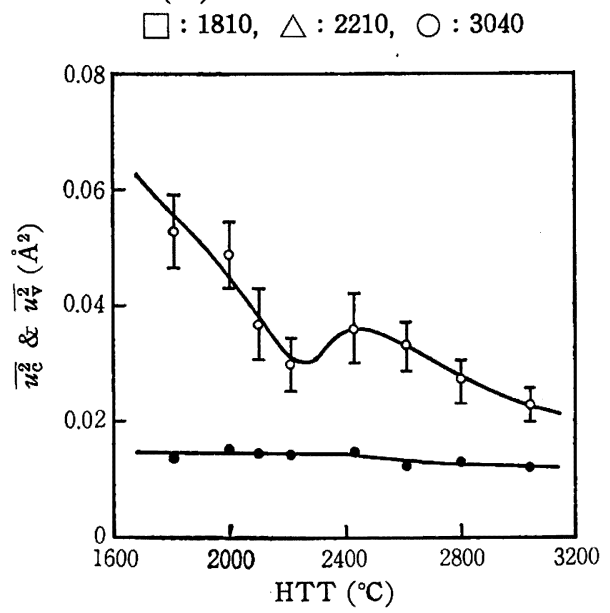

Fig. 2 Variation in mean-square displacement $\overline{u_{\mathrm{c}}^{2}}$ and mean-square thermal vibrational displacement $\overline{u_{\mathrm{v}}^{2}}$ of carbon atoms at room temperature

$$
\bigcirc: \overline{u_{\mathrm{c}}^{2}}, \bigcirc: \overline{u_{\mathrm{v}}^{2}}
$$

5）白石 稔，小林和夫，日化，1973，1291.

\section{$3.2 \overline{\boldsymbol{u}_{\mathrm{c}}^{2}}$ と $\boldsymbol{c}_{0}$ との関係}

$c$ 軸長 $c_{0}$ と $\overline{u_{c}^{2}}$ の関係を見ると四 3 のと怙りである。 $c_{0}$ が約 $6.85 \AA$ まで減少するにつれて $\overline{u_{\mathrm{c}}^{2}}$ は急激に減少する。さらに $c_{0}$ が減少すると $\overline{u_{\mathrm{c}}^{2}}$ は若干增加し, 約 $6.80 \AA$ より $c_{0}$ がさらに減 少するとふたたび $\overline{u_{\mathrm{c}}^{2}}$ は減少しはじめる。

\section{$3.320^{\circ} \mathrm{C}$ における $\overline{u_{\mathrm{v}}^{2}}$ および $\overline{u_{\mathrm{v}}^{2}}$ の温度依存性}

炭素原子の熱振動によって生ずる $c$ 軸方向への $20^{\circ} \mathrm{C}$ に打ける 二乗平均変位 $\overline{u_{\mathrm{v}}^{2}}$ の HTT による変化を図 2 に示した5)。HTT $1810^{\circ} \mathrm{C}$ から $2430^{\circ} \mathrm{C}$ の箸囲では $20^{\circ} \mathrm{C}$ に括ける $\overline{u_{\mathrm{v}}^{2}}$ はほぼ 0.015 $\AA^{2}$ を示す。HTT が $2430^{\circ} \mathrm{C}$ 以上に増加すると, $\overline{u_{\mathrm{v}}^{2}}$ は減少して $3040^{\circ} \mathrm{C}$ では約 $0.012 \AA^{2}$ を示す。

一方, $\overline{u_{\mathrm{v}}^{2}}$ の温度変化は四 4 に示すように大きく, 測定温度に ほ注比例して増加している。 $3040^{\circ} \mathrm{C}$ 処理カーボンの場合, $\overline{u_{\mathrm{v}}^{2}}$ は $20^{\circ} \mathrm{C}$ で $0.012 \AA^{2}$ から $400^{\circ} \mathrm{C}$ で $0.025 \AA^{2}$ K, $1000^{\circ} \mathrm{C}$ では 0.047 $\AA^{2}$ に增大する。これは炭素原子が $c$ 軸方向へその平衡位置を中 心に $20^{\circ} \mathrm{C}$ で平均 $0.11 \AA, 1000^{\circ} \mathrm{C}$ で $0.22 \AA$ の振幅で熱振動し ていることを示している。

\section{$3.4 \overline{u_{\mathrm{s}}^{2}}$ と $c_{0}$ との関係}

$\overline{u_{\mathrm{c}}^{2}}$ は炭素原子が平均的な層面からそれと垂直方向に变位して いる大きさを表わしている。そしてそれは炭素原子の静的な变位 の二乗平均 $\overline{u_{\mathrm{s}}^{2}}$ と熱振動による変位の二乗平均 $\overline{u_{\mathrm{v}}^{2}}$ の和である゙。 $\overline{u_{\mathrm{s}}^{2}}$ を $\overline{u_{\mathrm{c}}^{2}}$ と $\overline{u_{\mathrm{v}}^{2}}$ の差として求め, $c_{0}$ との関係を示すと図 3 のよ らになる。 $\overline{u_{\mathrm{c}}^{2}}$ と $c_{0}$ との関係とほぼ同様の傾向の曲線が得られ た。 $c_{0}$ が約 $6.85 \AA$ まで減少するにつれて, $\overline{u_{\mathrm{s}}^{2}}$ は急激に減少し,

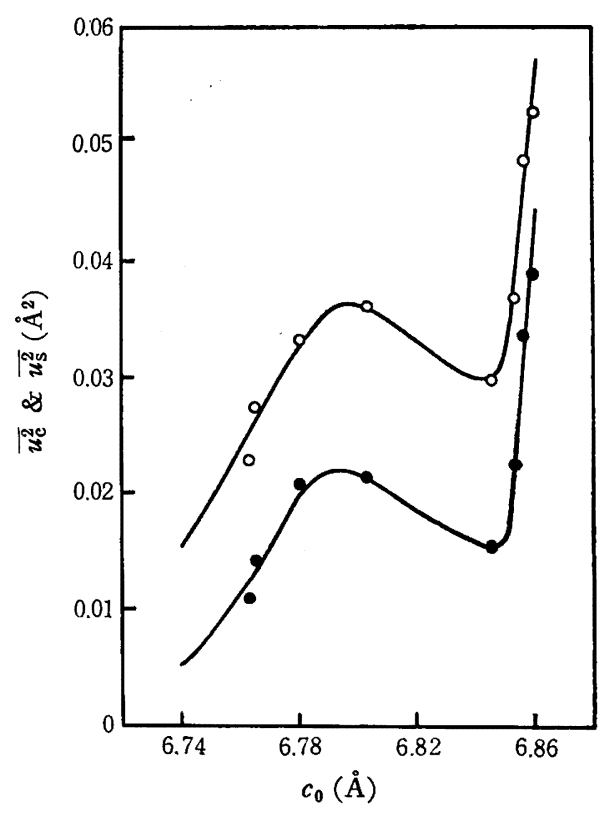

Fig. 3 Variation of mean-square displacement $\overline{u_{\mathrm{c}}^{2}}$ and mean-square static displacement $\overline{u_{\mathrm{s}}^{2}}$ with $c$-axis spacing $c_{0}$

$$
\bigcirc: \overline{u_{\mathrm{c}}^{2}}, \bigcirc: \overline{u_{\mathrm{s}}^{2}}
$$

6）平均的な層面からある变位している原子への距離を $u_{\mathrm{s}}$ ，そ の熱振動の大きさを $u_{\mathrm{v}}$ とすれば，ある瞬間において層面 からその原子への距離 $u_{\mathrm{c}}$ は $u_{\mathrm{c}}=u_{\mathrm{s}}+u_{\mathrm{v}}$ と表わせる。 た， $u_{\mathrm{s}}$ が多くの炭素原子について正規分布にしたが 5 確 率をるって現われるとすれば， $u_{\mathrm{c}}$ の多くの原子の平均を 求めると次式が得られる， $\overline{u_{\mathrm{c}}^{2}}=\overline{u_{\mathrm{s}}^{2}}+\overline{u_{\mathrm{v}}^{2}}$ 


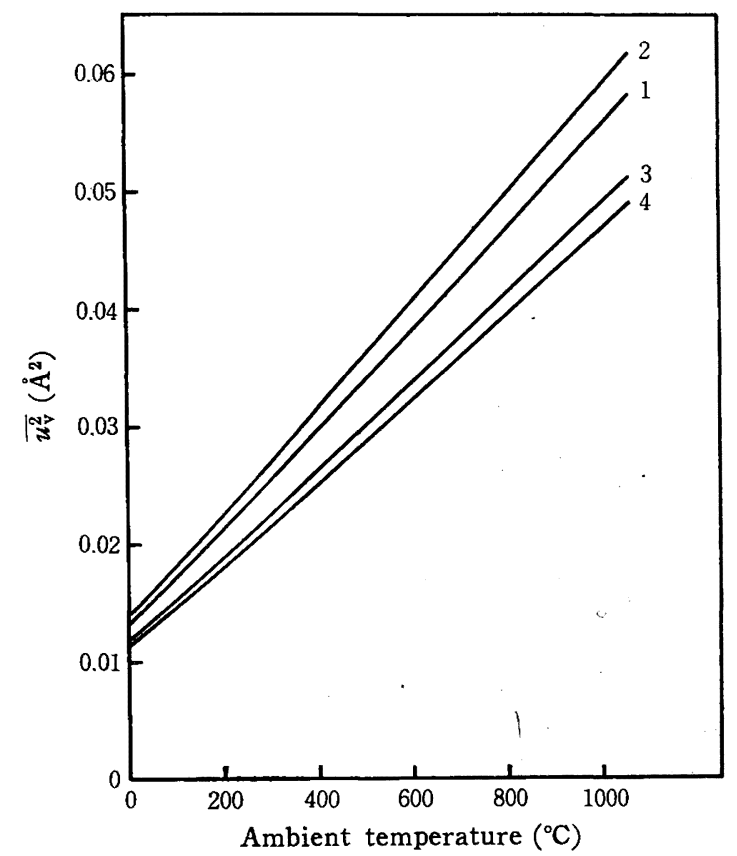

Fig. 4 Variation of mean-square thermal vibrational displacement $\overline{u_{\mathrm{v}}^{2}}$ with ambient temperature HTT $\left({ }^{\circ} \mathrm{C}\right)-$

$1: 1810,2: 2430,3: 2610,4: 3040$

さらに $c_{0}$ が $6.80 \AA$ 付近まで減少すると， $\overline{u_{\mathrm{s}}^{2}}$ はわずかに大きく なり，さらに $c_{0}$ が小さくなると $\overline{u_{\mathrm{s}}^{2}}$ はふたたび減少する。全体 としてカーボンの黒鉛化が進むにつれて, $\overline{u_{\mathrm{s}}^{2}}$ は減少する。しか し，3040ㄷ で熱処理した XF カーポンでるかなり大きな $\overline{u_{\mathrm{s}}^{2}}$ 示し, $0.011 \AA^{2}$ の值にとどまっている。

\section{4 考察}

$4.1 \overline{u_{\mathrm{c}}^{2}}$ の精度と HTT, $c_{0}$ に対する $\overline{u_{\mathrm{c}}^{2}}, \overline{u_{\mathrm{S}}^{2}}$ の変化

六方晶系に属する結晶の $00 l$ 反射強度の対数と $\sin ^{2} \theta / \lambda^{2}$ の関 係は直線になるはずである。しかし, 図1から明らかなよらに $\log I_{\mathrm{obs}} / I_{0}$ は完全には直線上にのらず, かなりのバラッキが認め られた。また，008 強度が弱くデータとして採用されなかったた めに, 直線の勾配の值から算出した $\overline{u_{\mathrm{c}}^{2}}$ の精度はかなり悪い。 $\log I_{\mathrm{obs}} / I_{0}$ のバラッキの括すな原因として, $00 l$ 強度の測定精度， とくに 006 プロフィルと 112 プロフィルの分離にさいして生ずる 誤差を含んでいる 006 強度の精度, 補正係数の適否などが考方ら れる。112 プロフィルは $\mathrm{Cu} K_{a}$ 線を使用した場合には高角側に現 われるので，その対称性はよい。したがって，006，112 プロフ ィルの分離として, 112 プロフィルの頂点からの垂線に対称に 112 プロフィルの低角側のプロフィルを高角側に折りかえし，も とのプロフィルとの差が006プロフィルになるとして分離した。 このような分離法にはかなり任意性が入る可能性がある。そこ で，このような分離による006 強度がどのくらい:シックかを見 た。HTT $2610^{\circ} \mathrm{C}$ の試料についてそれは約 $10 \%$ 程度であった。 これは $\overline{u_{\mathrm{c}}^{2}}$ の $0.004 \AA^{2}$ 程度の誤差に相当し, 図 2 に示した $\overline{u_{\mathrm{c}}^{2}}$ の誤差とほぼ同程度である。一方, 補正係数でもっとも誤差の原 因となるすのは吸収因子の決定と思われる。これについては本実 験では，各試料ごとに線吸収係数を求めて Milberg の式)から吸
収係数を算出しているので，適切な方法と思われる。いずれにし ても，図1に示した程度のバラッキが見られた。そして， $\overline{u_{\mathrm{c}}^{2}}$ の 大きい試料の 004, 006 相対強度は $\overline{u_{\mathrm{c}}^{2}}$ の小さい試料のそれより 必ず小さかった。

$\overline{u_{\mathrm{c}}^{2}}$ の確率誤差を計算した結果が図 2 の縦線で示されている。誸 差はかなり大きく平均 $\pm 0.005 \AA^{2}$ 程度であった。この誤差を考 慮に入れて図 2 の $\overline{u_{\mathrm{c}}^{2}}$ と HTT との関係を見ると, HTT $2400^{\circ} \mathrm{C}$ 付近 $\left(c_{0} \approx 6.80 \AA\right)$ で, それより HTT の低い範囲之高い範囲に 特ける $\overline{u_{\mathrm{c}}^{2}}$ の変化のようすが翼なっていることがわかる。すなわ ち, HTT $2430^{\circ} \mathrm{C}$ で $\overline{u_{\mathrm{c}}^{2}}$ の測定点はピークを示すが, 誤差の大き さを考えて $\overline{u_{\mathrm{c}}^{2}}$ の変化を見ると $\mathrm{HTT} 2400^{\circ} \mathrm{C}$ 付近でピークは示 さずとも，その前後で $\overline{u_{\mathrm{c}}^{2}}$ の変化に屈曲が見られる。

$\mathrm{HTT}$ の增加にともなって，c軸長 $c_{0}$ は $2200 \sim 2600^{\circ} \mathrm{C}$ の範 囲で急激に減少し, $\mathrm{HTT} 2400^{\circ} \mathrm{C}$ 付近はもっとも $c_{0}$ の変化のは げしい熱処理温度の範囲である ${ }^{5}$ 。 $2400^{\circ} \mathrm{C}$ に熱処理された試料の $c_{0}$ は $6.80 \AA$ 程度である。 $\overline{u_{\mathrm{c}}^{2}}$ の異状すこの HTT 付近, この $c_{0}$ の付近に相当している。この現象は石油コークスの場合にも認め られだ)。

熱振動による变位を除いた炭素原子の静的な変位の二 乗 平均 $\overline{u_{\mathrm{S}}^{2}}$ の $c_{0}$ に対する挙動は図 3 に示したように, X線回折プロフィ ルの Fourier 変換によって求めた $c$ 軸方向のヒズミ $\bar{\delta}_{\mathrm{c}}^{2}{ }^{8)}$ および $\mathrm{X}$ 線回折プロフィルの半価幅から求めた $c$ 軸方向のヒズミ $\varepsilon_{\mathrm{c}}{ }^{9}$ の $c_{0}$ に対する变化と似ている。これらのことから，易黒鉛化性炭 素の少なくともある炭素は層面に属する炭素原子の $c$ 軸方向への バラシキ，または層面間距離のバラシキの黒鉛化過程に拈ける変 化が $c_{0}>6.85 \AA$ と $c_{0}<6.85 \AA$ で大きく異なり, さらに, $c_{0}<$ $6.85 \AA$ の範囲では $6.80 \AA$ 付近に変化があることが考劣られる。

\section{$4.2 \overline{u_{\mathrm{v}}^{2}}$ の温度变化}

Kelly ${ }^{10)}$ は黑鉛中の炭素原子の熱振幅の温度変化を理論的に算 出している。それによると面外振動の大きさは室温で $0.09 \AA$ 程 度から $1000^{\circ} \mathrm{C}$ で約 $0.2 \AA$ まで増大している。本実験で得られた $\sqrt{\overline{u_{\mathrm{v}}^{2}}}$ の温度変化の曲線は, Kelly の計算した黒鉛の面外振動の 大きさの温度変化の曲線と傾向はよく一致している。ただし, 絶 対値は本実験の温度範囲で $3040^{\circ} \mathrm{C}$ 処理カーボンの方が Kelly の値より約 $0.02 \AA$ 大さい。本実験で使用した試料は黒鉛化の程 度が非常によいとはいい難い。それにもかかわらず両曲線の傾向 はよい一致を示している。しかし，黒鉛化の進行にともなら $\overline{u_{v}^{2}}$ の減少はわずかにとどまり，黒鉛化が進むにつれて $\overline{u_{\mathrm{v}}^{2}}$ が減少し て，黒鉛のそれに近づく明らかな傾向は本試料では見られなかっ

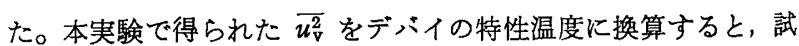
料の HTT の上昇につれて, $500^{\circ} \mathrm{K}$ からわずかに增加して $580^{\circ} \mathrm{K}$ を示した。一方，黒鉛のデハイイの特性温度としては約 $800 \%$ の央 験結果が報告されている(1)。これらのことから，本実験で使用し たカーボンはいずれる完全結晶である黒鉛よりも $c$ 軸方向への炭 素原子の熱振動が大きく，デハイの特性温度は低い。このことは 使用したカーボンの $c$ 軸方向の炭素原子の結合力は黒鉛のそれよ

7) M.E. Milberg, J.Appl.Phys., 29, 64(1958).

8) C. Schiller, J. Mering, P. Cornuault, F. Du Chaffaut, Carbon, 5, 385(1967).

9）稲垣道夫, 炭素, No.71, 124(1972).

10) B. T. Kelly, Carbon, 10, 324(1972).

11) A. Magnus, Ann.Phys. Lpz., 70, 303(1923) ; G. Albinet, J.P. Biberian, M. Bienfair, Phys. Rev., B 3, 2015(1971). 


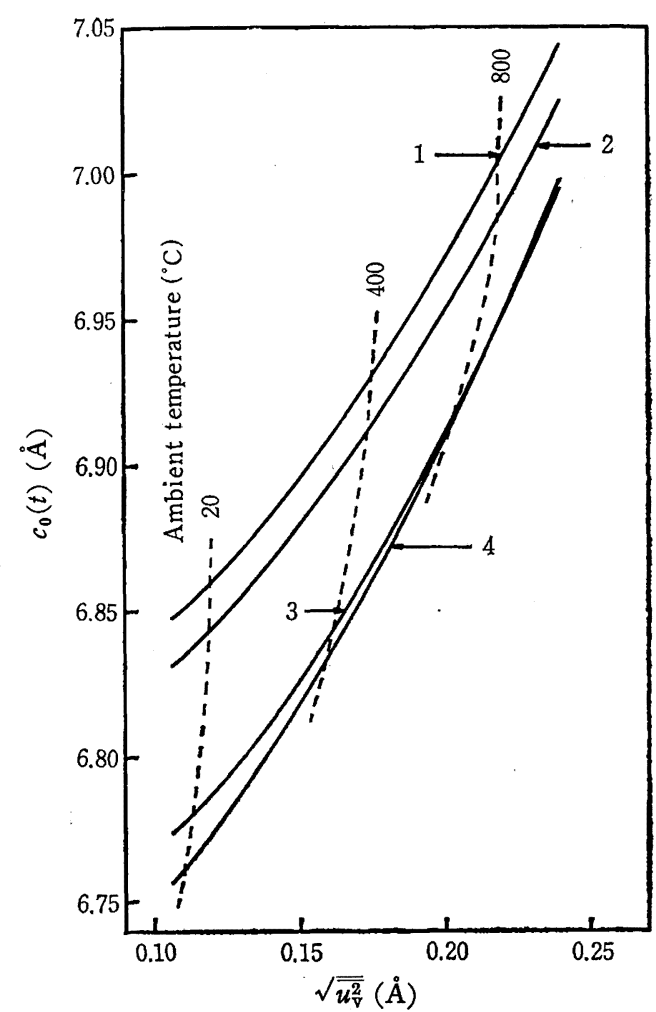

Fig. 5 Variation of $c$-axis spacing $c_{0}(t)$ with rootmean-square thermal vibrational displacement $\sqrt{\overline{u_{\mathrm{v}}^{2}}}$

$\operatorname{HTT}\left({ }^{\circ} \mathrm{C}\right)$

$1: 1810,2: 2210,3: 2610,4: 3040$

り弱いことを示唆している。

熱振動による二乗平均変位の大きさ $\overline{u_{\nabla}^{2}}$ は図 4 に示したように

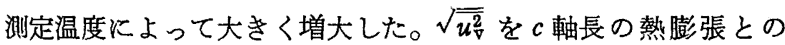
関係で見ると図 5 のようになる。どの試料についても，測定温度 が高くなり $\sqrt{\overline{u_{\mathrm{v}}^{2}}}$ が大きくなると $c_{0}$ の変化率，すなわち図 5 中 の曲線の勾配が大きくなる。また， $3040^{\circ} \mathrm{C}$ 処理の試料ではこの 勾配は他の試料のそれにくらべてやや大きい。測定温度の高温側 では各試料間のこの勾配の差が小さくなる。一方, 測定温度の低 温側に打いてこの勾配は HTT の低い試料では小さく, HTT が 高くなると大きくなっている。そして，HTT の低い試料では HTT の高い試料にくらべて，測定温度の低温側で熱振動の同じ 変化量に対して層面間の熱膨張が若干小さいことがわかる。実測 した各試料の室温から約 $900^{\circ} \mathrm{C}$ ま゙の平均の熱膨張は, $3040^{\circ} \mathrm{C}$ 処理試料でわずかに大きいが，他の試料ではほとんど相違がなか った。これはHTT の低い試料ほと增面間距離が大きく，また $\overline{u_{\mathrm{S}}^{2}}$ が大さいために $\overline{u_{\mathrm{v}}^{2}}$ の層面間の熱膨張へおよぼす効力が測定 温度の低温側では HTT の高い試料とは異なっていると思われ る。測定温度が上昇すると $\overline{u_{\mathrm{v}}^{2}}$ が大きくなり，㬝面間の熱膨張に $\overline{u_{\mathrm{v}}^{2}}$ の寄与が大きくなるために図 5 中の各試料の勾配が近づくと 思われる。

Kellett ら $\left.{ }^{12}\right)$ が求めた $\sqrt{\overline{u_{\mathrm{v}}^{2}}}-d_{002}$ 曲線の勾配は $1200^{\circ} \mathrm{C}$ 以上の 湘定温度で一定で，試料の差異によらず $d_{002}$ の熱膨張とほぼ同

12) E. A. Kellett, B.P. Jackets, B.P. Richards, Carbon, 2, 175 (1964).

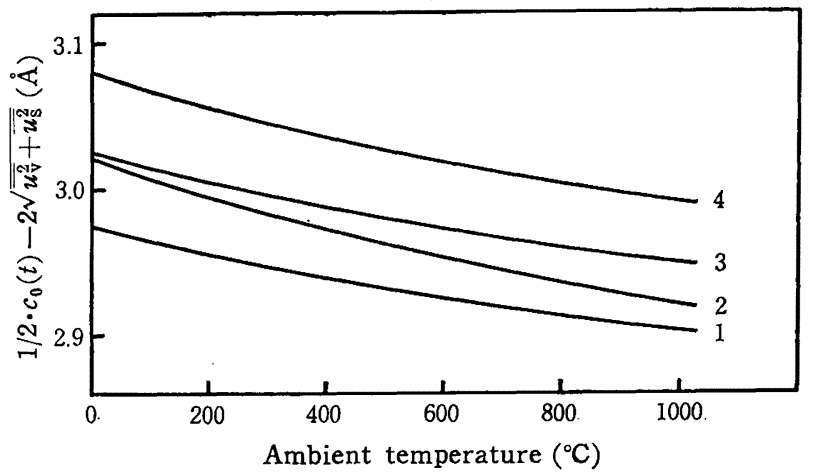

Fig. 6 Variation of "free space" with ambient temperature

HTT $\left({ }^{\circ} \mathrm{C}\right)$

$1: 1810,2: 2430,3: 2610,4: 3040$

じ割合で $\sqrt{\overline{u_{\mathrm{v}}^{2}}}$ す増大していた。本実験で得られた高温側の勾配 は約 2 で Kellett らの結果と一致した。

\section{3 free space の温度変化}

以上のように，測定温度が上昇するにしたがって $\overline{u_{\mathrm{v}}^{2}}$ が大きく なり， $c$ 軸長も熱膨張する。一方, 試料中の層面に属する炭素原 子の静的な変位は本実験の測定温度の範囲内では測定温度が上昇 しても各試料ごとに一定であると考えられるが，試料によってそ の値は異なっている。そこで，これらの值の温度に対する相対的 変化を見るために，層面間中に平均として原子が存在しない空 間, free space ${ }^{12)}$ を考えてみる。free space は次式から求めた。

$$
\text { free space }=\frac{1}{2} c_{0}(t)-2 \sqrt{\overline{u_{\mathrm{v}}^{2}}(t)+\overline{u_{\mathrm{s}}^{2}}}
$$

黒鉛状の結晶構造から考えても free space 中にまったく炭素 原子が存在しないとは考文難いが，平均的に見れば炭素原子が存 在しないと考宇られる。

4 試料の free space の温度変化を図 6 に示した。free space は測定温度の上昇にともなって減少する。そして，その減少の割 合は測定温度が高くなると減少する傾向が見られた。1000C に おいてすべての試料の free space は約 $2.9 \AA$ 以上の大きさを示 している。この大きな free space のために， $c$ 軸長の熱膨張は free space にくらべて小さい炭素原子の $c$ 軸方向の静的变位に あまり影響されないのであろら。

このように free space が測定温度の上昇にともなって減少す ることは, 層面の熱膨張よりも層面の平均厚さ $2 \sqrt{\overline{u_{\mathrm{c}}^{2}}}$ の熱膨張の 方が大きいことを意味している。さらに，測定温度が上昇して試 料の HTT 以上になると $\overline{u_{v}^{2}}$ は大きくなり, free space は小さ くなるので炭素原子の $c$ 軸方向への再配列が起こり，炭素の黒鉛 化が進行するすのと思われる。

\section{4 石油コークスとの比較}

$\mathrm{XF}$ 炭は $3040^{\circ} \mathrm{C}$ で熱処理しても $c_{0}$ はかなり大きく6.76

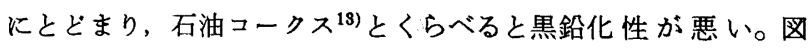
$7 \mathrm{a}$ に示すように, $\overline{u_{\mathrm{c}}^{2}}$ と HTT との関係は両試料とす傾向は類 似しているが, $\mathrm{XF}$ カーボンは $2400^{\circ} \mathrm{C}$ 付近に屈曲があり，石油 コークスでは $2200^{\circ} \mathrm{C}$ 付近にピークがある。そして同じHTTに 対する $\overline{u_{\mathrm{c}}^{2}}$ の值は $\mathrm{HTT} 2200^{\circ} \mathrm{C}$ の試料を除いて, XF カーポン 13）白石 稔, 小林和夫, 豊田貞治, 工化, 74, 1331(1971). 

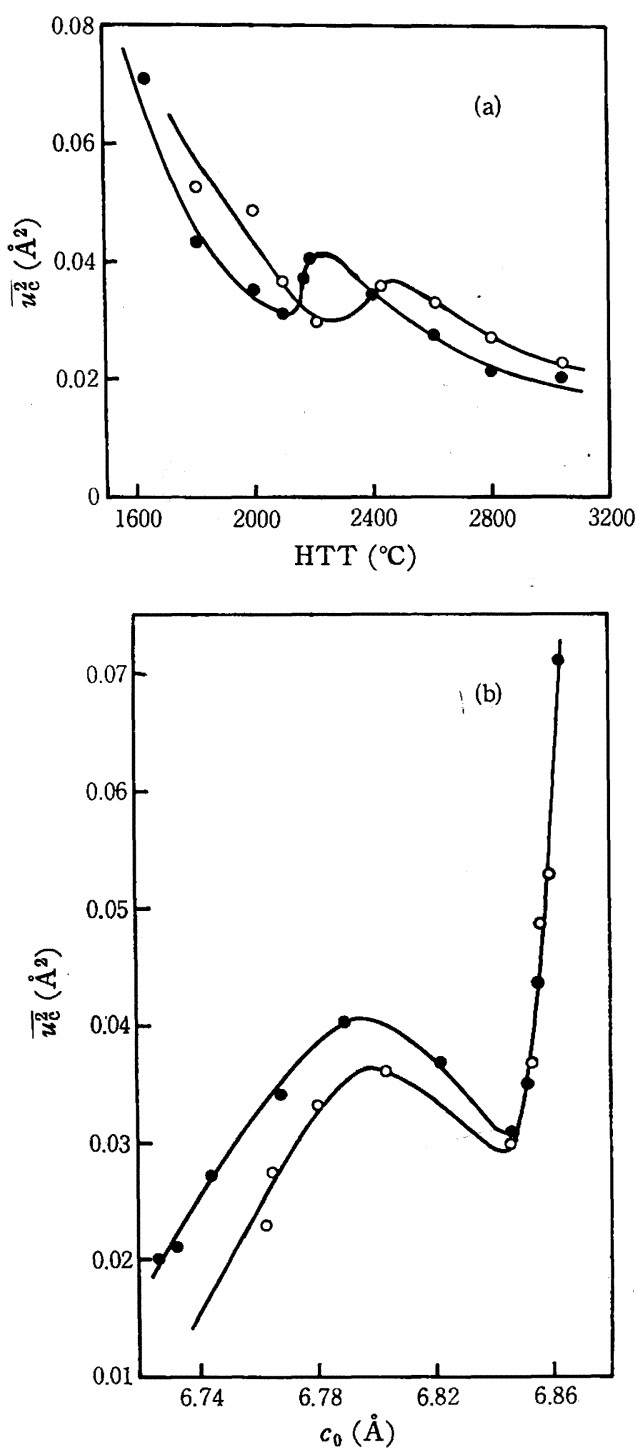

Fig. 7 Comparison of $\overline{u_{c}^{2}}$ in $\mathrm{XF}$ carbon with that in petroleum coke

$$
\mathrm{O} \text { : XF carbon, : Petroleum coke }
$$

の方が大きいしかし，図 $7 \mathrm{~b}$ に明らかなように， $\overline{u_{\mathrm{c}}^{2}}$ と $c_{0}$ との 間の関係では $c_{0}>6.85 \AA$ では両試料は同一曲線上にあるが, $c_{0}<6.85 \AA$ では同一曲線上になく, XF カーボンの $\overline{u_{\mathrm{c}}^{2}}$ の方が石 油コークスのそれより小さくなっている。
一方, $20^{\circ} \mathrm{C}$ に打ける $\overline{u_{\mathrm{v}}^{2}}$ の值は, HTT の高い方では XF カ 一ボンも石油コークスもともに約 $0.012 \AA^{2} を$ 示す。しい, HTT の低い方では XF カーボンの方がやや大きい值を示した。 また, $\overline{u_{v}^{2}}$ の温度変化は両試料ともに測定温度に比例して大きく 增大した。

free space は測定温度が室温から $1000^{\circ} \mathrm{C}$ まで上昇するにつれ て, XF カーボンで約 $0.08 \sim 0.10 \AA$, 石油コークスで $0.06 \sim$ $0.10 \AA$ 減少した。

このように両試料の HTT, 測定温度にともなう $\overline{u_{\mathrm{c}}^{2}}, \overline{u_{\mathrm{v}}^{2}}$ の変 化は傾向としては類似していた。ただし，XF カーボンの $\overline{u_{\mathrm{s}}^{2}}$ と 石油コークスのそれとをくらべると，HTT と対しては前者が大 きく, $c_{0}$ に対しては $c_{0}<6.85 \AA$ で前者が小さい結果が示され た。XF カーボンの方が石油コークスにくらべて黑鉛化性がわる いので, $c_{0}$ に対しても $\overline{u_{\mathrm{s}}^{2}}$ が大きくでるだろらと予想していた が，結果は逆であった。この原因については今後の研究にまつほ かない。

\section{5 結 論}

$\mathrm{XF}$ 炭を $1800^{\circ} \mathrm{C}$ から $3000^{\circ} \mathrm{C}$ まで熱処理して得たカーボンの 002，004，006 反射強度の測定および 004 強度の温度変化からつ ざの結果を得た。

(1) $\overline{u_{\mathrm{V}}^{2}}$ の值は $20^{\circ} \mathrm{C}$ で $0.015 \AA^{2}$ から $0.012 \AA^{2}$ の範囲にあ った。そして， $\overline{u_{\mathrm{v}}^{2}}$ は測定温度に比例して増大した。

（2）すべての試料に対して層面間距離の熱膨張よりも層面自 身の平均厚さ $\left(2 \sqrt{\overline{u_{\mathrm{c}}^{2}}}\right)$ の熱膨張の方が大きい。そして, 測定温 度が高くなると層面間距離特よび $\sqrt{\overline{u_{\mathrm{v}}^{2}}}$ の温度变化の比は等しく なる傾向があった。このことから，どの試料についてすほぼ同一 の層面間の平均熱膨張を示すことが理解された。

(3) $\overline{u_{\mathrm{S}}^{2}}$ は $c_{0}>6.85 \AA$ で $c_{0}$ が減少するにつれて急激に減少 して, $c_{0} \approx 6.85 \AA$ で $0.015 \AA^{2}$ を示す。 $c_{0}$ が約 $6.85 \AA$ から $6.78 \AA$ の範囲では $\overline{u_{\mathrm{s}}^{2}}$ の值定值は約 $0.019 \AA^{2}$ を示し, さらに $c_{0}$ が減少すると $\overline{u_{\mathrm{S}}^{2}}$ も減少する。

黒鉛化の進行にともならある層面に属する炭素原子の $c$ 軸方向 への変位の大きさの挙動は $c_{0}>6.85 \AA$ と $c_{0}<6.85 \AA$ で異なり, さらに $c_{0}<6.85 \AA$ では $c_{0} \approx 6.80 \AA$ で屈曲があることが知られ た。

（4） XF カーボンと石油コークスを比較すると， $c_{0}, L_{\mathrm{c}}$ から 判断するかぎり前者の方が後者より黑鉛化性が悪い。それにもか かわらず, $\overline{u_{\mathrm{v}}^{2}}$ の值およびそれの温度変化, $\overline{u_{\mathrm{s}}^{2}}$ の $c_{0}$ に対する変 化は類似していた。

\title{
Atomic Displacement along $c$-Axis and Its Temperature Dependence in 3,5-Xylenol-Formaldehyde Resin Carbon
}

\author{
Minoru Shiraishi and Kazuo Kobayashi \\ National Research Institute for Pollution and Resources; Kotobuki-cho, \\ Kawaguchi-shi 332 Japan
}

A series of studies are being undertaken in order to clarify the variation of the layer structure in graphitization process. In this paper, on the 3,5-xylenol-formaldehyde resin carbon samples heat-treated at $1800^{\circ} \mathrm{C}$ to $3000^{\circ} \mathrm{C}$, the mean-square displacement, $\overline{u_{\mathrm{c}}^{2}}$, and the mean-square thermal vibrational displacement, $\overline{u_{\mathrm{v}}^{2}}$, of carbon atoms perpendicular to layer planes were calculated from X-ray diffraction intensities of 002,004 and 006 reflections. 
The value of $\overline{u_{\mathrm{c}}^{2}}$ decreased abruptly with the decrease in $c_{0}$ from $6.86 \AA$ to $6.85 \AA$, and showed about $0.033 \AA^{2}$ up to $6.78 \AA$, and then decreased again with the decrease in $c_{0}$ (Fig. 3). The values of $\overline{u_{\mathrm{v}}^{2}}$ were in the range of $0.015 \sim 0.012 \AA^{2}$ at $20^{\circ} \mathrm{C}$ and increased with ambient temperature (Figs. 2 and 4 ).

The 3,5-xylenol-formaldehyde resin carbon was found to be less graphitizing than the petroleum coke studied previously from the variations of $c_{0}$ and $L_{c}$ with heat-treatment temperature. However the variations of $\overline{u_{\mathrm{c}}^{2}}$ with $c_{0}$ and of $\overline{u_{\mathrm{v}}^{2}}$ with ambient temperature were similar on both samples. 